\title{
LETTER
}

\section{Selective digestive decontamination is superior to selective oropharyngeal decontamination}

\author{
Luciano Silvestri ${ }^{*}$, Nia Taylor ${ }^{2}$, Durk F Zandstra ${ }^{3}$ and Hendrick KF van Saene ${ }^{2}$ \\ See related research by Schultz and Haas, http://ccforum.com/content/15/1/R18
}

We are interested in the debate on the efficacy and safety of selective digestive decontamination (SDD) and selective oropharyngeal decontamination (SOD) raised by Schultz and Haas in their review [1].

The authors concluded that 'SDD and SOD are equally effective with respect to the prevention of mortality' [1]. This statement is based on the results of a Dutch randomized controlled trial [2], which was the first to demonstrate a survival benefit of SOD. However, the mortality reduction was higher, albeit not significantly, in the SDD group than in the SOD group. Additionally, a recent meta-analysis, including nine SOD randomized controlled trials and 4,733 patients, failed to show any significant mortality reduction (odds ratio $(\mathrm{OR})=0.93$; $95 \%$ confidence interval $(\mathrm{CI})=0.81$ to 1.07 ) [3]. In contrast, there is robust evidence indicating that SDD including parenteral and enteral antimicrobials significantly reduces mortality [4].

The authors wrote that 'whether SDD or SOD are favorable with regard to development of antibiotic resistance is yet unknown' [1]. The Dutch randomized controlled trial, however, showed that patients with aerobic Gram-negative bacilli in rectal swabs resistant to the marker antibiotics numbered less with SDD than with SOD [2]. Additionally, bacteremia due to highly resistant pathogens was significantly reduced by SDD compared with SOD (OR $=0.37,95 \% \mathrm{CI}=0.16$ to 0.85 ), and lower respiratory tract colonization due to highly resistant pathogens was lower with $\mathrm{SDD}(\mathrm{OR}=0.58,95 \%$ $\mathrm{CI}=0.43$ to 0.78$)$ than with $\mathrm{SOD}(\mathrm{OR}=0.65,95 \% \mathrm{CI}=$ 0.49 to 0.87 ) compared with standard care [5].

We believe that SDD is superior to SOD in terms of both mortality reduction and emergence of resistance.
Abbreviations

$\mathrm{Cl}$, confidence interval; $\mathrm{OR}$, odds ratio; SDD, selective digestive decontamination; SOD, selective oropharyngeal decontamination.

\section{Competing interests}

The authors declare that they have no competing interests.

\section{Author details}

'Department of Emergency, Unit of Anesthesia and Intensive Care, Presidio Ospedaliero, Via Fatebenefratelli 34, 34170 Gorizia, Italy. ${ }^{2}$ School of Clinical Sciences, University of Liverpool, Liverpool L69 3GA, UK. ${ }^{3}$ nntensive Care Unit, Onze Lieve Vrouwe Gasthuis, 1090 HM Amsterdam, The Netherlands.

\section{Published: 18 March 2011}

\section{References}

1. Schultz MJ, Haas LE: Antibiotics or probiotics as preventive measures against ventilator-associated pneumonia: a literature review. Crit Care 2011, 15:R18.

2. de Smet AM, Kluytmans JA, Cooper BS, Mascini EM, Benus RF, van der WerfTS, van der Hoeven JG, Pickkers P, Bogaers-Hofman D, van der Meer NJ, Bernards AT, Kuijper EJ, Joore JC, Leverstein-van Hall MA, Bindels AJ, Jansz AR, Wesselimk RM, de Jongh BM, Dennesen PJ, van Asselt GJ, te Velde LF, Frenay

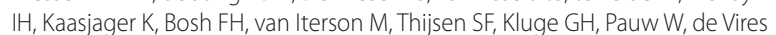
JW, Kaan JA, et al.: Decontamination of the digestive tract and oropharynx in ICU patients. N Engl J Med 2009, 360:20-31.

3. Silvestri L, van Saene HKF, Zandstra DF, Viviani M, Gregori D: SDD, SOD or oropharyngeal chlorhexidine to prevent pneumonia and to reduce mortality in ventilated patients: which manoeuvre is evidence-based? Intensive Care Med 2010, 31:1436-1437.

4. Silvestri $L$, van Saene HK, Weir I, Gullo A: Survival benefit of the full selective digestive decontamination regimen. J Crit Care 2009, 24:474.e7-474.e14.

5. de Smet AM, Kluytmans J, Blok H, Bonten M, Bootsma M: Effects of selective digestive and selective oropharyngeal decontamination on bacteraemia and respiratory tract colonization with highly resistant micro-organisms [abstract]. Clin Microbiol Infect 2010, 16(Suppl 2):S98.

\section{doi:10.1186/cc10068}

Cite this article as: Silvestri $L$, et al: Selective digestive decontamination is superior to selective oropharyngeal decontamination. Critical Care 2011,

15:411.

\footnotetext{
*Correspondence: Iucianosilvestri@yahoo.it

'Department of Emergency, Unit of Anesthesia and Intensive Care, Presidio

Ospedaliero, Via Fatebenefratelli 34, 34170 Gorizia, Italy

Full list of author information is available at the end of the article
} 